\title{
Promoting Green Growth in China's New Development Stage Through Tax Reform
}

\author{
Fu Zhihua ${ }^{1}$, Cheng Yu ${ }^{2}$ \\ ${ }_{1,2}$ Chinese Academy of Fiscal Sciences, Beijing 100142, China \\ 1 fuzhihua@sina.com \\ 2 chengyu@163.com
}

\begin{abstract}
Green growth is not only an important way to build ecological civilization and promote economic transformation, but also the core essence of ensuring high-quality economic development in the new development stage. Optimization of tax system design is a key measure to release institutional dividend to promote green development. From the perspective of tax reform, this paper analyzes the current situation and the challenges of tax greening in China in recent years, and puts forward general thoughts and suggestions on how to promote green development at the new stage so as to create a two-wheel drive mechanism of carbon tax and environmental protection tax, lead the structural reform of China's tax system, continuously improve tax regulation, and construct a green tax system with multiple taxes and means to cooperate with each other and to regulate it comprehensively and effectively.
\end{abstract}

Keywords: tax reform, new stage of development, green development

JEL: Q52, Q53, Q56

For citation: Fu Zhihua, Cheng Yu. Promoting Green Growth in China's New Development Stage Through Tax Reform. Financial Journal, 2021, vol. 13, no. 5, pp. 44-50.

https://doi.org/10.31107/2075-1990-2021-5-44-50.

(c) Fu Zhihua, Cheng Yu, 2021

\section{INTRODUCTION}

Green development, or green growth is a high-quality development model that takes social economy and ecological environment into consideration. It is of great significance to protect the global ecological environment and achieve inclusive and sustainable economic growth. As the largest developing country in the world, China advocates the concept of green development and takes the corresponding road, which is not only the correct choice in line with the general trend of the times, but is also going to have a positive demonstration effect on the international community.

In 2015, China put forward the development concept of "innovation, coordination, green, openness and sharing." The concept of green development is deeply rooted in the hearts of the people and can be embodied in the relevant system and policy formulation. The ecological civilization is written into the Constitution; "Clear waters and green mountains are as good as mountains of gold and silver," is written into the CPC Constitution; the top-level 
design system of ecological civilization construction is basically established; central finance continues to increase investment; and the battle against pollution is progressing smoothly. Environmental control has been effective. At the same time, China has actively participated in global environmental governance, assumed the responsibility of the Paris Convention, taken the lead in issuing the China National Plan for the Implementation of the 2030 Sustainable Development Agenda, and hosted the fifteenth Conference of the Parties to the Convention on Biological Diversity, which has become an important force in promoting global sustainable development. In September 2020, President Xi Jinping made a commitment to the international community at the general debate of the seventy-fifth session of the United Nations General Assembly, declaring that "China will peak its $\mathrm{CO}_{2}$ emissions by 2030 and strive to achieve carbon neutralization by 2060" (hereinafter referred to as "carbon peak \& neutralization"). This reflects China's position as a responsible country, and demonstrates that China's green development will face more arduous tasks and severe challenges. It is urgent to expand its thinking on the relevant system design, policy mechanism and implementation path.

Green growth involves many fields of economic development and ecology protection, which requires a combination of fiscal, tax, financial, industrial, scientific and technological system design and policy formulation. Among them, the green level of the tax system is one of the important indices to measure green development of a country or region. From the perspective of tax reform, this paper will analyze the current situation and the challenges of tax greening in China in recent years, and put forward general thoughts and suggestions on how to promote green development at the new development stage, so as to create a two-wheel drive mechanism of carbon tax and environmental protection tax, lead the structural reform of China's tax system, continuously improve tax regulation, and construct a green tax system with multiple taxes and means to cooperate with each other and to regulate it comprehensively and effectively.

\section{PROGRESS AND EVALUATION OF CHINA'S GREEN TAX SYSTEM IN RECENT YEARS}

\section{Effectiveness of the Progress}

In recent years, especially since 2016, China has focused on promoting environmental protection tax legislation and resource tax reform and legislation. At the same time, the green regulation mechanism is optimized in the aspects of consumption tax, value-added tax, enterprise income tax, vehicle purchase tax, etc. A multi-level green tax system has been established to have promoted the green transformation of tax system and raised the level of rule of law in the green tax system.

First, the introduction of environmental protection tax has milestone significance in the construction of the green tax system. The Environmental Protection Tax Law was adopted by vote on December 5, 2016 and was fully implemented on January 1, 2018. For the first time, China has an independent environmental protection tax for pollution emissions and environmental behavior, and the construction of the green tax system has entered a new stage of legalization, specialization and refinement.

Second, the reform and legislation of resource tax is another important progress in the construction of the green tax system. Since July 2016, China has fully implemented the reform of ad valorem resource tax collection, started a pilot project of water resource tax reform and gradually expanded the scope of the pilot project. On August 26, 2019, the Standing Committee of the Thirteenth National People's Congress adopted the Resource Tax Law, which has taken effect from September 1, 2020. The reform and legislation of resource tax have constructed the automatic adjustment mechanism of tax and resource price, standardized the relationship between resource tax and fee, and further strengthened the function of resource tax in promoting rational development and use of resources and the protection of the ecological environment. 
Third, the green adjustment function of multiple taxes has been further improved. China continues implementing the policy of exempting new energy vehicles from vehicle purchase tax and the preferential policies of vehicle and vessel tax for energy-saving and new energy vehicles and vessels; optimizing and adjusting the preferential policies of value-added tax on comprehensive utilization of resources for products and services; and levying a consumption tax of $10 \%$ on super luxury cars in the retail sector since December 1,2016 . Through strengthened incentive and restraint mechanism of existing taxes in energy saving and emission reduction, the green tax system is further improved.

\section{Existing Problems}

On the whole, China's green tax system has taken a breakthrough step, the green level of the tax system has been further improved, and tax constraints and incentives have been effectively brought into play, encouraging energy conservation and emission reduction, and promoting the improvement of the ecological environment. But from the overall point of view of economic development and environmental protection, China's transition from "light green" and "soft green" to "deep green" and "hard green" still needs great efforts. The green degree of the tax system is not enough to meet the high requirement of green low-carbon development under the new situation.

First, a strong regulatory tool for carbon emissions is lacking. In the process of

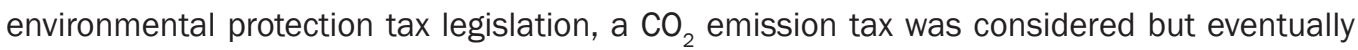
abandoned for various reasons. In the current consumption tax, resource tax, vehicle and vessel tax, vehicle purchase tax rate setting and preferential policies, there is no consideration of carbon emissions.

Second, the adjustment ability of green tax needs to be improved. Environmental protection tax has just been launched, the main taxpayer only covers $1 / 10$ of the emitting entities in the country, the tax rate level needs to be improved, volatile organic compounds (VOCs) are not included in the tax scope as a whole, and preferential policies need to be upgraded. The role of environmental protection tax has not been fully brought into play. The resource tax is mainly aimed at the collection of mineral resources; the level of tax rate is low; the intrinsic value of resources is not fully reflected; the pilot process of water resources tax is slow; and the collection of resource tax on renewable resources such as forest, grassland and beach resources is difficult in the system design and supporting conditions, which restricts the role of resource tax in protecting natural resources and the ecological environment.

Third, green adjustment of other taxes needs to be deepened. The scope of consumption tax collection is narrow, and the tax burden level of energy resource products is on the low side as a whole. The enterprise income tax carries out catalogue management on preferential income of environmental protection, special energy-saving and water-saving equipment and comprehensive utilization of resources, but the update of the catalogue lags behind the technological progress, which leads to the discount of encouragement. The preferential policies of value-added tax on comprehensive utilization of products and services are too piecemeal, and are subject to the chain deduction mechanism and the practice of collection and management, which not only has a poor implementation effect, but also destroys the neutrality of the value-added tax.

\section{NEW SITUATIONS AND REQUIREMENTS FACING CHINA'S GREEN TAX SYSTEM IN THE NEW DEVELOPMENT STAGE}

The 14th Five-Year Plan puts forward that, since 2021, China has entered a new stage of development, and the focus of economic and social development will shift from "high growth 
rate" of economic scale to improving efficiency and quality, and achieving "high quality" development has become a new theme. At this new stage, the country is going to face more severe resource and environmental constraints and emission reduction pressure, which poses a new challenge to the greening of China's tax system. It is urgent to strengthen the regulation of the tax system and to speed up the process of green tax system construction. This is evident in the following two areas.

\section{International and Domestic Pressure on Carbon Emission Reduction}

Global climate change, characterized mainly by warming, has been the greatest threat to human society in the 21st century. Energy, environment and climate security have become the top issues of the highest political meetings in the world. China is not only one of the countries most affected by global climate change, but also a major energy consumer and greenhouse gas emitter, which has an important impact on global climate change. President Xi Jinping, after making the "carbon peak \& neutralization" commitment at the United Nations General Assembly in September 2020, stressed again at the ninth Central Finance and Economics Commission meeting in March 2021 that the realization of "carbon peak \& neutralization" is a broad and profound economic and social systemic change. In the international environment, in 2021, the European Parliament adopted a resolution on the European Union's carbon border adjustment mechanism (CBAM), which is compatible with the WTO, carbon tariffs are emerging, and the impact on the global economy and trade is expected to gradually appear. Therefore, actively addressing climate change and strengthening the formulation and implementation of carbon pricing mechanisms are not only endogenous requirements for China's economic and social development, but also an active response to the international community's responsibility concerning environmental issues such as carbon emission reduction. This can be a positive response to international trade barriers and unfair trade policy countermeasures.

\section{Internal Requirements of the New Development Pattern}

At the new stage of development, we should take the new concept as the guide, speed up the construction of a new development pattern with the big domestic cycle as the main body and the domestic and international double cycles to promote each other, and contribute to high-quality development of the economy. Green growth is an important part of the new development concept. The construction of tax system should be guided by the framework of green growth, accelerate the pace of green adjustment of tax system, strengthen the guidance and restraint function of tax system for the behavior of market subjects, and promote the construction of ecological civilization.

\section{GENERAL THOUGHTS AND RECOMMENDATIONS FOR THE GREENING OF CHINESE TAX SYSTEM}

\section{General Thoughts}

The adjustment and optimization of China's tax system guided by "green" is an important way to carry out the major strategy of ecological civilization construction and realize the goal of carbon peak and carbon emission reduction. Considering the reality's urgency and the national conditions, we believe that the overall idea of greening the tax system in the new stage of development is to create a two-wheel drive mechanism of carbon tax and environmental protection tax to lead the structural reform of China's tax system, constantly improve the intensity of tax regulation, and build a green tax system with multiple taxes and various means to cooperate with each other. 


\section{Recommendations}

First, establish a separate special carbon tax as a strong policy tool for carbon emission reduction. In order to achieve the goal of carbon peak and carbon neutralization, it is far from enough to rely on the current domestic carbon trading system and the regulation mechanism of the existing taxes. It is necessary to increase the tax burden of fossil fuels as soon as possible to increase the cost of carbon emissions and form a more powerful constraint mechanism on the main body of carbon emissions. There are several policy options for collecting carbon tax: one is to reform the resource tax, the other is to reform the consumption tax, the third is to increase the tax on carbon dioxide emissions in the environmental protection tax, and the fourth is to levy a special tax on carbon alone. There are advantages and disadvantages in each of the four approaches, but, in a comprehensive way, we believe that the policy of levying a standalone carbon tax is stronger, more effective, more conducive to achieving the policy objectives of carbon emission reduction, and more conducive to responding to international pressure and international policy coordination. In the system design of carbon tax, we should grasp the pace of reform, carry out the strategy of distribution, start with low tax rate, carry out dynamic adjustment, and steadily raise the level of tax rate. At the same time, it is necessary to coordinate the carbon tax with the resource tax, consumption tax and carbon trading system, so as to avoid an excessive increase in the burden of enterprises in the short term.

Second, further optimize the system design of environmental protection tax. In addition to carbon emission reduction, environmental protection tax should become the vanguard of green tax system construction and give full play to its control function of pollution prevention and control. For this reason, the environmental protection tax law should be revised as soon as possible to deepen the reform of the environmental protection tax system, including the following: establishing linkage with the emission permit management system to bring more pollution discharge subjects into the scope of the taxpayer of environmental protection tax; steadily raising the tax rate level so that the tax rate can fully reflect the cost of environmental treatment; bringing all VOCs into the scope of taxation as soon as possible; adjusting and optimizing preferential tax policies such as tax exemption for pollution treatment plants and strengthening their restraint and incentive mechanism.

Third, speed up the green transformation of existing taxes. Fully consider the attributes of the existing taxes to implement green transformation. Further increase the tax burden on the use of scarce resources, high pollution and high energy consuming mineral products; improve the mechanism for the formation of the price of resource products; speed up the relevant research on system design; and implement the reform of the water resources tax and the resources tax on forests, grasslands and beaches throughout the country as soon as possible. Adjust the scope of consumption tax, establish a dynamic adjustment mechanism, according to the requirements conducive to energy conservation and emission reduction-some products that do not meet the technical standards of energy conservation and environmental protection as well as other high energy consumption, high pollution and serious consumption of resources can be subject to consumption tax. Optimize the structure of consumption tax rate, appropriately adjust the tax rate, further implement differential tax rates, expand the difference in tax rate according to the degree of environmental pollution of taxable products and consumption of resources (or energy), play the better role of consumption tax in promoting energy conservation and emission reduction, and provide reasonable guidance on consumption. The tax basis of motor vehicle consumption tax and vehicle and vessel tax can be levied according to $\mathrm{CO}_{2}$ emissions, and the differential tax rate can be applied. Standardize the preferential policies of value-added tax, abolish the policy of value-added tax refund on the basis of comprehensive utilization of resources, and enhance the neutral characteristics of value-added tax. Adjust the catalogue of preferential policies 
related to enterprise income tax in time so as to eliminate the obstacles for enterprises to enjoy preferential tax policies.

Fourth, we should fully consider the principle of tax neutrality in tax system greening, and focus on improving the ability and strength of tax system to regulate resources and environment through tax system adjustment. The goal of tax system greening is to encourage green development rather than to obtain income. Therefore, while introducing carbon tax and raising the current tax burden, we should avoid increasing the overall tax burden of enterprises and residents. On the one hand, the adjustment of the green tax system should be accompanied by the implementation of other tax reduction measures-through the reduction of value-added tax, income tax, social security contributions and other forms of increased tax returns to enterprises and residents. On the other hand, it is necessary to formulate tax compensation policies for low-income groups. Since environmental protection taxes (including carbon taxes), consumption taxes and other taxes have a certain recluse nature, the price of energy and related products may rise as a result and thus increase the tax burden on low-income groups. Therefore, in order to reduce the impact on low-income groups and maintain social stability, it is necessary to give corresponding relief and concessions: for example, the coal and natural gas used by residents can be given lower tax rates. An increase of fiscal transfer expenditure to low-income groups via corresponding compensation may also be considered.

\section{References}

Aldy J. E., Krupnick A. J., Newell R. G. et al. (2009). Designing Climate Mitigation Policy. NBER Working Paper 15022, pp. 816.

CAFS Research Group (2018). Selecting Appropriate Opportunities to Levy Carbon Tax While Actively Promoting Carbon Emissions Trading. Public Finance Research, 2018(04), pp. 2-19.

Krass D., Nedorezov T. (2011). Environmental Taxes and the Choice of Green Technology. SSRN working paper.

Lü H., An Y.F., Sun T.T. (2018). Influence of Carbon Tax on Enterprises' Production and Emission Reduction from the Perspective of Learning Effect. Science and Technology Management Research, 38(19), pp. 266-262.

Meng S., Siriwardana M., McNeill J. (2013). The Environmental and Economic Impact of the Carbon Tax in Australia. Environmental and Resource Economics, 64(3), pp. 313-332.

Murray B. C., Newell R. G., Pizer W. A. (2009). Balancing Cost and Emissions Certainty: An Allowance Reserve for Cap-and-Trade. Review of Environmental Economics and Policy, 3(1), pp. 84-103.

Poyago-Theotoky J. (2007). The Organization of R\&D and Environmental Policy. Journal of Economic Behavior \& Organization, 62(1), pp. 63-75.

Toptal A, Özlü H, Konur D. (2014). Joint Decisions on Inventory Replenishment and Emission Reduction Investment Under Different Emission Regulations. International Journal of Production Research, 52(1), pp. 243-269.

Tsai W.H. (2020). Carbon Emission Reduction-Carbon Tax, Carbon Trading, and Carbon Offset. Energies, 13(22).

Valdés R.M.A., Comendador V.F.G., Campos L.M.B. (2021). How Much Can Carbon Taxes Contribute to Aviation Decarbonization by 2050. Sustainability, 13(3), pp. 1-13.

Zhang B., Xu C.H. (2013). Condition and Dynamic Adjustment of Carbon Tax. China Population, Resources and Environment, 23(06), pp.16-20.

Zhang G.T., Cheng P.Y., Sun H. et al. (2021). Carbon Reduction Decisions Under Progressive Carbon Tax Regulations: A New Dual-Channel Supply Chain Network Equilibrium Model. Sustainable Production and Consumption, vol. 27, pp. 1077-1092.

Zhao X.G, Wu L., Zhou Y. (2020). How to Achieve Incentive Regulation Under Renewable Portfolio Standards and Carbon Tax Policy? A China's Power Market Perspective. Energy Policy, 143(C):111576. 


\title{
Information about the authors
}

Fu Zhihua, PhD (Economics), Deputy President and Researcher, Chinese Academy of Fiscal Sciences, Beijing

Cheng Yu, PhD (Economics), Researcher, Chinese Academy of Fiscal Sciences, Beijing

Article submitted May 5, 2021

Approved after reviewing September 23, 2021

Accepted for publication October 15, 2021

https://doi.org/10.31107/2075-1990-2021-5-44-50

\section{Содействие зеленому развитию Китая посредством налоговой реформы}

Фу Чжихуа, PhD (Economics), заместитель президента и научный сотрудник Китайской академии финансовых наук, Пекин

Чэн Ю, PhD (Economics), научный сотрудник Китайской академии финансовых наук, Пекин

\begin{abstract}
Аннотация
"Зеленое" развитие преАставляет собой не только путь к созданию экологической цивилизации и к экономическим преобразованиям, но и основу Аля реализации качественного экономического роста на новом этапе развития Китая. Ключевой мерой по высвобождению институциональных среАств Аля соАействия "зеленому" развитию выступает оптимизация налоговой системы. В настоящей статье в контексте налоговой реформы проанализированы текущая ситуация и проблемы экологизации налогообложения в Китае последних лет, а также представлены общие тезисы и предложения о том, как способствовать "зеленому" развитию на новом этапе, включая запуск Авойного механизма, сочетающего налог на выбросы углерода и экологический налог, провеАение структурной реформы налоговой системы Китая, постоянное совершенствование налогового регумирования и создание системы "зеленого" налогообложения с комплексом налогов и среАствами Аля сотрудничества и всестороннего, эффективного регулирования.
\end{abstract}

Ключевые слова: налоговая реформа, новый этап развития, “зеленое» развитие

JEL: Q52, Q53, Q56

Аля цитирования: Фу Чжихуа, Чэн Ю. Содействие зеленому развитию Китая посреАством налоговой реформы // Финансовый журнал. 2021. Т. 13. № 5. С. 44-50.

https://doi.org/10.31107/2075-1990-2021-5-44-50.

(С) Фу Чжихуа, Чэн Ю, 2021

Статья поступила в редакцию 05.05.2021

ОАобрена после рецензирования 23.09.2021

Принята к публикации 15.10.2021 